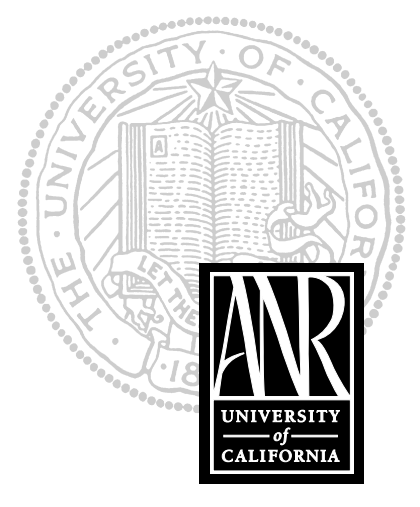

UNIVERSITY OF CALIFORNIA

Division of Agriculture and Natural Resources

http://anrcatalog.ucdavis.edu
PUBLICATION 8010

\section{Chestnut Culture in California}

PAUL VOSSEN, University of California Cooperative Extension Farm Advisor, Sonoma County

$\mathbf{T}$ he chestnut is a delicious nut produced on large, magnificent trees on millions of acres of native habitat in the Northern Hemisphere, particularly in China, Korea, Japan, and Southern Europe. The entire eastern half of the United States was once covered with native chestnut trees until a blight fungus introduced from Asia destroyed them in the early 1900s. The fleshy nut is sweet with a starchy texture and has a low fat content, resembling a cereal grain. The nuts are eaten as traditional foods in much of Asia and Europe, where they are consumed fresh, cooked, candied, and as a source of flour for pastries.

The chestnut tree is in the same family as beeches and oaks (Fagaceae). The formidable, spiny chestnut burr is the equivalent of the cap on an acorn. Chestnuts belong to the genus Castanea, with four main economic species: C. dentata (North American), C. mollissima (Chinese), C. sativa (European), and C. crenata (Japanese). It is not related to the horse chestnut (Aesculus spp.). The tree has gray bark and is deciduous, with leaves that are 5 to 7 inches $(12.5$ to $18 \mathrm{~cm}$ ) long, sharply serrated, oblong-lanceolate, and pinnately veined. Domestication of the chestnut is still progressing, with much of the world's production collected from natural stands.

\section{SPECIES}

Four species of chestnut are grown in North America (see table 1). They exist as pure species or, more commonly, as hybrids of the various species because they readily cross with one another. In many cases, it is difficult to distinguish species and almost impossible to visually determine the parentage of the hybrids.

- Castanea crenata. The Japanese chestnut is native to China and Japan, where it grows into a dense slender tree attaining a height of about 50 feet $(15 \mathrm{~m})$. The tree is very resistant to most known diseases, but the nut flavor is considered inferior to other species.

- Castanea dentata. The American chestnut is native to the Appalachian forests of the United States from Maine to Georgia and as far west as Michigan and

Table 1. Chestnut (Castanea) species grown in North America

\begin{tabular}{|c|c|c|c|c|c|}
\hline Species & $\begin{array}{c}\text { Common } \\
\text { name }\end{array}$ & $\begin{array}{l}\text { Height in } \\
\text { feet }(m)\end{array}$ & Nut size & Nut flavor & $\begin{array}{c}\text { Blight } \\
\text { resistance }\end{array}$ \\
\hline C. crenata & Japanese chestnut & $\begin{array}{c}40-60 \\
(12-18)\end{array}$ & varies & fair & some \\
\hline C. dentata & American chestnut & $\begin{array}{l}60-100 \\
(18-30)\end{array}$ & small & excellent & none \\
\hline C. mollissima & Chinese chestnut & $\begin{array}{l}30-50 \\
(9-15)\end{array}$ & medium & good & very high \\
\hline C. sativa & European chestnut & $\begin{array}{c}60-80 \\
(18-24)\end{array}$ & large & good & very low \\
\hline
\end{tabular}


Louisiana. The trees are huge timber types that are tall, straight, and columnar, reaching heights of 100 feet $(30 \mathrm{~m})$ or more with trunk diameters of 3 to 5 feet (90 to $150 \mathrm{~cm})$. The nuts are small, about 35 to the pound $(77 / \mathrm{kg})$, and are covered with thick, pale fuzz. Two or three are compressed in one burr. The nuts are said to be the sweetest and most flavorful of all the chestnuts. The species was virtually wiped out in the early 1900s by chestnut blight, caused by a fungus originally called Endothia parasitica but renamed Cryphonectria parasitica. The alien disease swept through the forests and caused one of our nation's worst ecological disasters, yet a few isolated stands still exist. American chestnuts are believed to be resistant to oak root fungus.

- Castanea mollissima. The Chinese chestnut is the smallest tree of all the species, growing to about 40 feet $(12 \mathrm{~m})$ tall. It is native to northern and western China. The nuts are generally medium in size and of good eating quality. Trees bear at a young age ( 3 years) and are the most resistant to chestnut blight. Nuts from Castanea mollissima average about 30 nuts per pound $(66 / \mathrm{kg})$. There are some exceptionally large cultivars of about 18 nuts per pound $(40 / \mathrm{kg})$, but these are not common. Average yield is 3 tons per acre (6.7 metric tons/ha), with up to 5.5 tons per acre (12.3 metric tons/ha) reported from dense plantings of 10 feet by 6 feet $(3 \mathrm{~m}$ by $1.8 \mathrm{~m})$ and high-yielding cultivars.

- Castanea sativa. The European chestnut is native to the temperate mountains of western Asia, Europe, and North Africa. Chestnuts growing in these areas seem to be quite tolerant of less-than-ideal conditions. The trees are large and spreading with a compact head; the nuts are much larger than the American species. Nut quality is quite variable, depending on the individual variety. These make up most of the imported nuts commonly seen in U.S. supermarkets.

\section{VARIETIES}

Several chestnut varieties have been selected in each species group, and breeding programs have recently produced many hybrids. Currently, in California, the principal cultivar is 'Colossal' (see fig. 1) grown with 'Silverleaf' (see fig. 2), 'Nevada,' 'Eurobella,' or 'Colossal Seedlings' as a pollenizer. 'Okei' is a promising new pollenizer for 'Colossal,' as it is vigorous, produces an abundance of pollen, and has large nut size, but it is a light bearer. Two new cultivars, 'Fowler' and 'Montesol,' produce excellent nuts that are very large; they are being investigated for commercial planting. Table 2 lists some of the varieties grown in the United States and their purported characteristics.

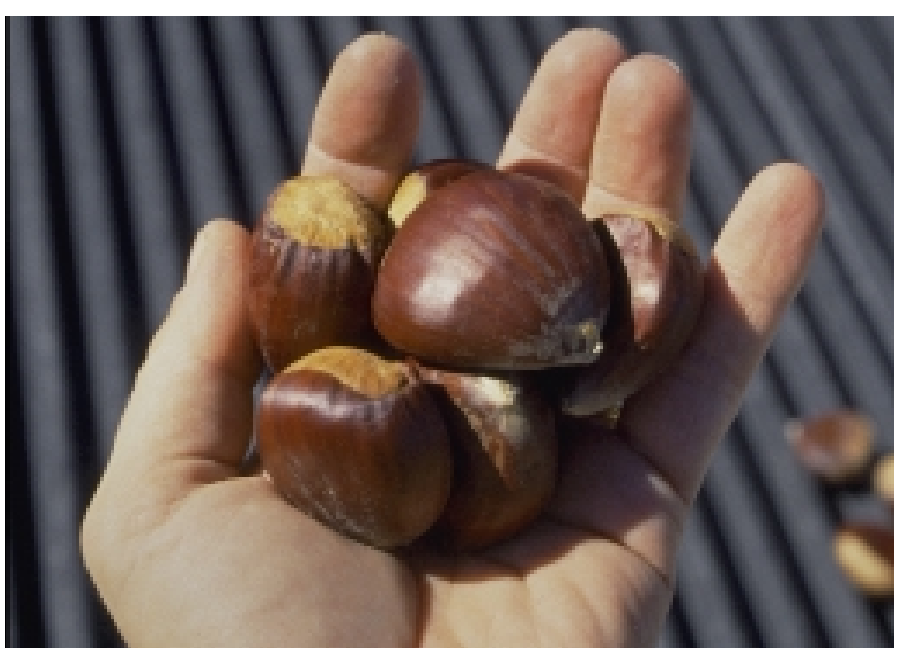

Figure 1. 'Colossal' chestnuts.

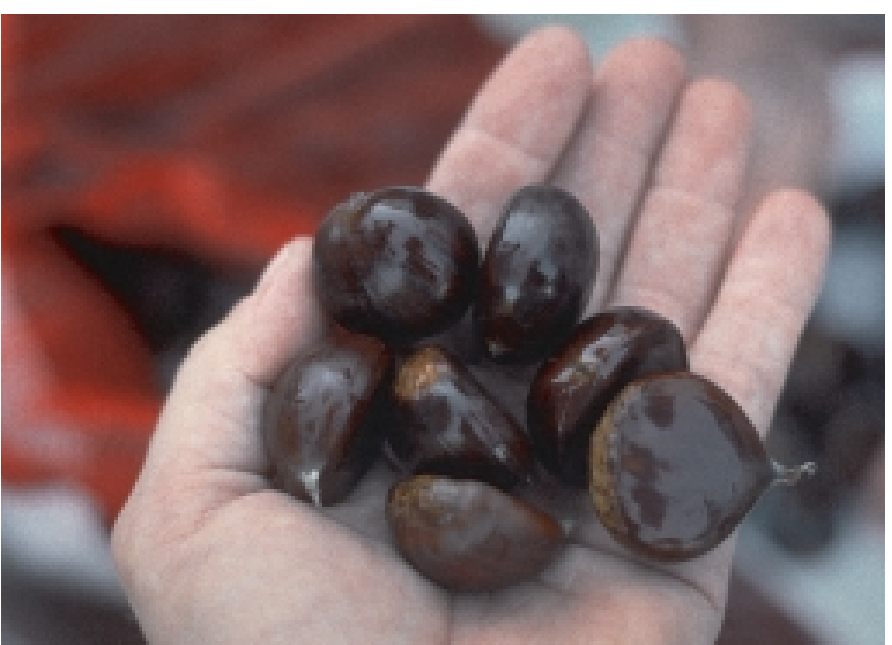

Figure 2. 'Silverleaf' chestnuts. 
Table 2. Selected chestnut varieties grown in the United States

\begin{tabular}{|c|c|c|}
\hline Variety & Type* & Comments \\
\hline Belle Epine & E & Pollenizer variety, resistant to root rot \\
\hline Borra & E & Large, high-quality Italian variety \\
\hline Bouche de Betizac & $E \times J$ & Standard of quality in France, resistant to root rot \\
\hline Caste Del Rio & E & Large, high-quality Italian variety \\
\hline Colossal & $E \times J$ & $\begin{array}{l}\text { Produces uniform-sized, very large, sweet nuts that average } 18 \text { per } \\
\text { pound }(40 / \mathrm{kg} \text { ), with a thick pellicle and some multiple embryos; } \\
\text { productive trees modestly susceptible to blight; the current industry } \\
\text { standard (see fig. 1) }\end{array}$ \\
\hline Crane & $\mathrm{C}$ & $\begin{array}{l}\text { Nuts average } 32 \text { per pound }(70 / \mathrm{kg}) \text {, with a dark red shell; good } \\
\text { keeper and excellent flavor }\end{array}$ \\
\hline Douglas hybrid & $C \times A$ & Good-sized nuts, late flowering, blight resistant \\
\hline Doyle & $E \times J$ & Selected 'Colossal' seedling of excellent quality \\
\hline Dunstan hybrids & $C \times A$ & Medium-sized nuts of very good quality, blight resistant \\
\hline Eurobella & $E \times J$ & Pollenizer for 'Colossal'; nuts are smaller than 'Colossal' \\
\hline Fowler & E & $\begin{array}{l}\text { Chance seedling of excellent quality and size with a 'Marrone'-type } \\
\text { nut (dark shell and papery pellicle rarely invaginated into the } \\
\text { cotyledons) }\end{array}$ \\
\hline Gellatly \#1 & C & Productive tree with sweet early nuts that fall free of the burr \\
\hline Ginyose & J & One of the best Japanese types, large nuts, resistant to gall wasp \\
\hline Lyeroka & $C \times E$ & $\begin{array}{l}\text { Early, productive, medium-sized, timber type tree, blight resistant, } \\
\text { pollen sterile }\end{array}$ \\
\hline Maraval & $E \times J$ & Excellent nut quality, slow to bear \\
\hline Marigoule & $E \times J$ & Pollenizer, productive, resistant to blight and root rot \\
\hline Marrone di Lucerna & E & High quality, resistant to root rot, large size \\
\hline Marrone di Marradi & $E$ & Large, high-quality nut grown in Italy east of Florence \\
\hline Montesol & $E$ & $\begin{array}{l}\text { Seedling selection that produces an abundance of very large nuts } \\
\text { with good quality }\end{array}$ \\
\hline Myoka & $C \times E$ & $\begin{array}{l}\text { Good producer of medium-sized nuts that stick in the burr but the } \\
\text { pellicle peels easily; good pollen producer, blight resistant }\end{array}$ \\
\hline Nevada & $E \times J$ & $\begin{array}{l}\text { Pollenizer for 'Colossal' that is very productive; nuts smaller than } \\
\text { 'Colossal' }\end{array}$ \\
\hline Okei & E & $\begin{array}{l}\text { Open-pollinated seedling of 'Silverleaf'; pollenizer for 'Colossal'; } \\
\text { a light bearer of very large nuts, } 16 \text { per pound }(35 / \mathrm{kg}) \text {, with } \\
\text { invaginated pellicle; shell tends to split at maturity; produces } \\
\text { abundant pollen }\end{array}$ \\
\hline Precoce Migoule & $E \times J$ & Excellent, large, striped nut, resistant to root rot \\
\hline Primato & $E \times J$ & Early leafing, bloom, and harvest \\
\hline Silverleaf & E & $\begin{array}{l}\text { Large, very sweet nut that peels easily, but the shell has a tendency } \\
\text { to crack; tree (see fig. 2) used as a pollenizer for 'Colossal' }\end{array}$ \\
\hline Skookum & $C \times E$ & $\begin{array}{l}\text { Cross of 'Lyeroka' and 'Myoka'; vigorous tree with medium-sized } \\
\text { sweet nuts }\end{array}$ \\
\hline Skioka & $C \times E$ & $\begin{array}{l}\text { Produces } 35 \text { to } 40 \text { nuts per pound ( } 77 \text { to } 88 / \mathrm{kg} \text { ) of good quality; } \\
\text { productive, sterile pollen }\end{array}$ \\
\hline Sleeping Giant & $C \times A \times J$ & Sweet, large nuts that fall free of the burr; vigorous, blight resistant \\
\hline Tsukuba & J & Large nut, good production, resistant to gall wasp \\
\hline Willamette & $C \times E$ & $\begin{array}{l}\text { Produces } 18 \text { to } 22 \text { nuts per pound ( } 40 \text { to } 48 / \mathrm{kg} \text { ) that are sweet } \\
\text { and easy to peel; timber-type tree }\end{array}$ \\
\hline
\end{tabular}

${ }^{*} \mathrm{~A}=$ American, $\mathrm{C}=$ Chinese, $\mathrm{E}=$ European, $\mathrm{J}=$ Japanese

\section{FLOWERING AND BEARING HABIT}

Chestnuts are monoecious, bearing both staminate (male) and pistillate (female) flowers on the same tree. They have mixed buds that break dormancy relatively late in the spring. As the shoots elongate from 1-year-old wood, staminate catkins emerge from lower nodes, and a few bisexual catkins grow from near the shoot tip. These bisexual catkins will have one or two pistillate flowers at their bases, the 
remaining flowers being staminate (see fig. 3). Each pistillate flower differentiates into three pistils within the burr or involucre. If pollinated, the ovaries of all three will develop into nuts; the middle one will be flattened. In some cultivars, two pistillate flowers fuse, resulting in four to six small, poorly shaped nuts.

Blossoming from mid-June to mid-July, the flowers evade spring frosts so that most cultivars will bear annually (see fig. 4). Catkins of some commercial cultivars, such as 'Colossal,' produce only a few or no staminate flowers. Other cultivars with staminate flowers may shed their pollen before the pistillate flowers are receptive, requiring cross-pollination. Bees and other insects are attracted to chestnut pollen, which has a distinct odor, but they do not seem to visit the pistillate flowers, presumably because the flowers lack nectar. Therefore, for the most part, chestnuts are wind-pollinated. Some research has demonstrated that the pollen parent can have an influence on the pollinated nut, especially with respect to size, a phenomenon called metaxenia. For example, pollen from a tree with large nuts could impart better size to its recipient than pollen from a tree that bears smaller nuts.

In the Central Valley of California, the burrs of 'Colossal' will begin to dehisce in mid-September, shedding the nuts (see figs. 5 and 6). On the North Coast of California, harvest does not begin until early October. Nuts will continue to drop for the next 3 to 5 weeks with or without the burr.

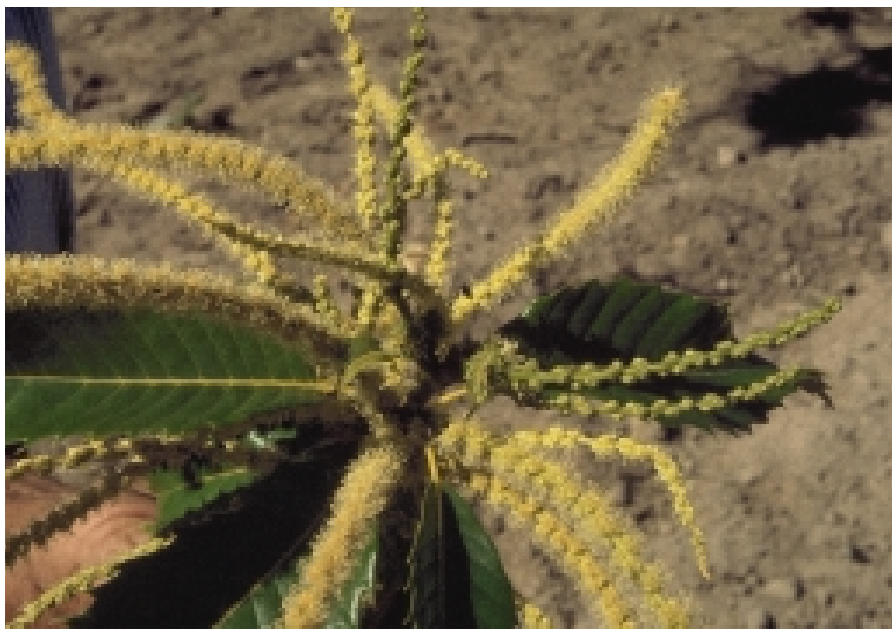

Figure 3. Male and female chestnut flowers.

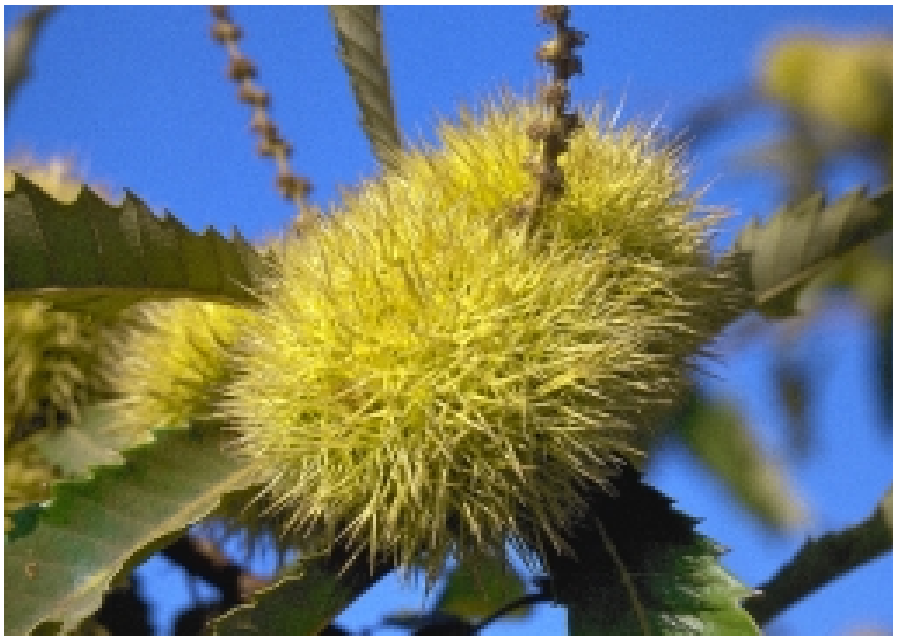

Figure 5. Close-up of a chestnut burr.

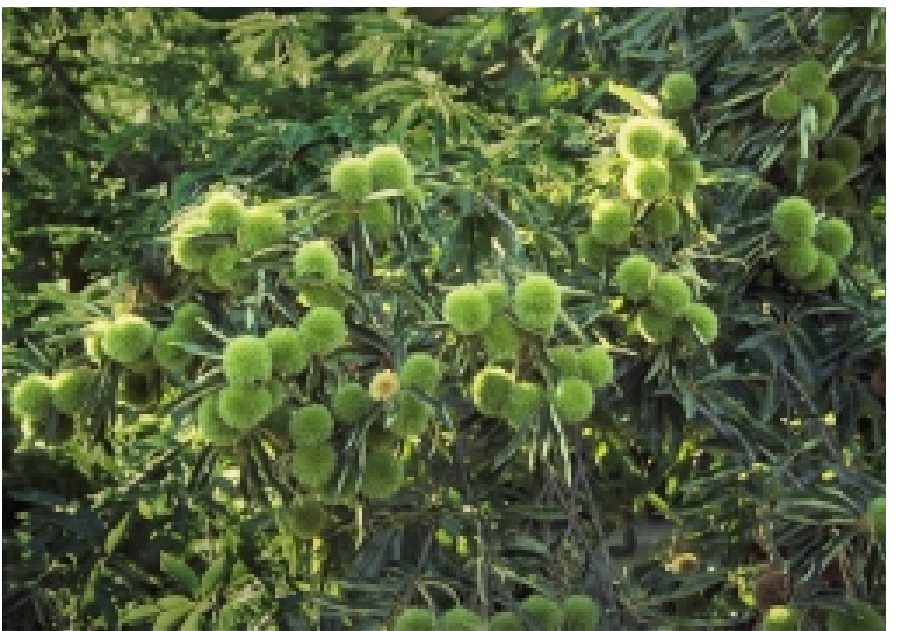

Figure 4. A good crop of 'Colossal' nuts.

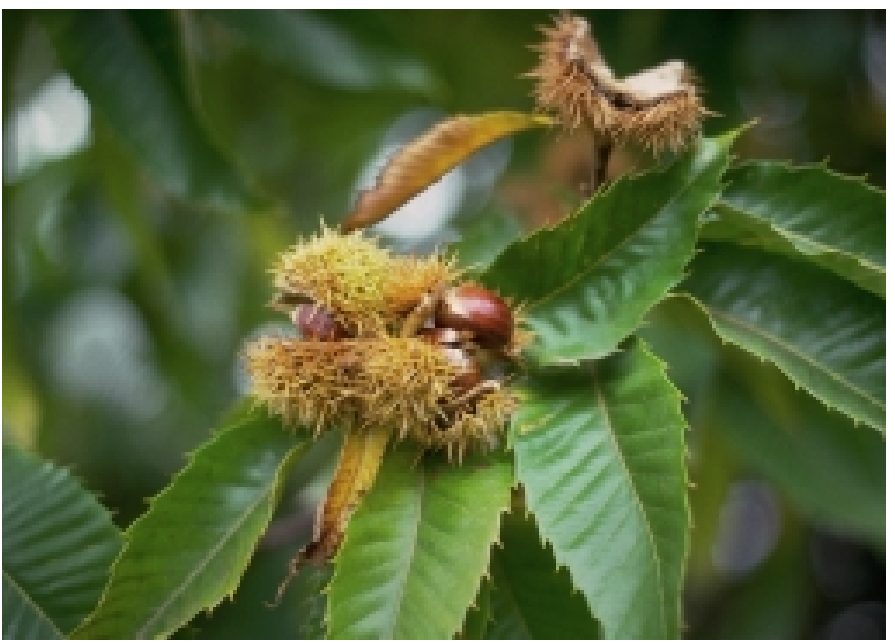

Figure 6. Chestnut burrs beginning to dehisce. 


\section{NUT CHARACTERISTICS AND USES}

The fruit of the chestnut is a large starchy nut with cream-colored cotyledons (meat) covered with an astringent membrane called the pellicle, which ranges in thickness from papery to a relatively thick woody tissue (see fig. 7). Some pellicles tend to adhere to the nut meat or intrude into the fissures and cracks in the cotyledons,

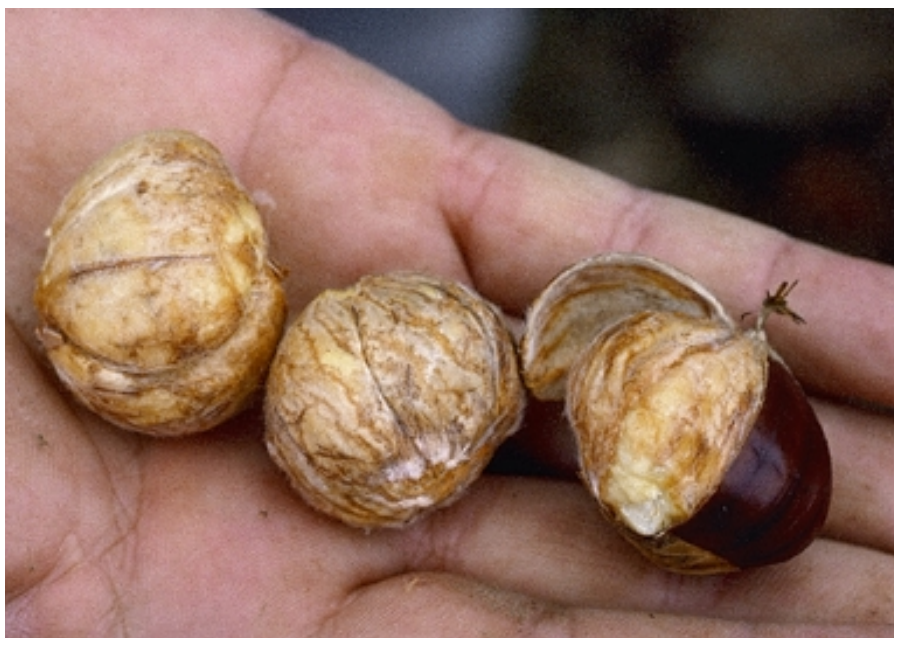

Figure 7. Chestnuts with shell removed. The pellicle is still attached to the cotyledons.

making peeling more difficult. The nut, with its leathery shell, is encased in a spiny burr, or involucre. The color of the shell ranges from black to brown to a striped golden yellow. The burr splits at maturity, usually exposing one to three nuts, but it may contain as many as seven. Nut size, degree of burr separation from the shell, ease of pellicle removal, and flavor are all very important quality characteristics.

The chestnut is essentially a grain growing on a tree. The nut contains about 40 percent carbohydrate, 40 percent water, 5 to 10 percent protein, and less than 5 percent oil (see table 3 ). Nutritionally, it is similar to other starchy foods such as potatoes, rice, or cereal grains. Chestnuts are receiving recognition as a health food, unlike other nuts, which contain well over 50 percent fat. Consisting mostly of starch, chestnuts also contain a very high-quality protein.

Traditionally, chestnuts have mainly been used in the United States for eating raw, boiled, or roasted, as in "chestnuts roasting on an open fire." The nut is very flavorful and sweet and can be used as an ingredient in turkey stuffing, sweet breads, cakes, soups, stir fry, cereals, and ice cream. Candied nuts, marrone glacé, are prized in Europe. Dried nuts can be ground into flour and used in diets for people with allergies to grains. In countries where chestnut culture is well established, chestnuts are used as a staple food, much as Americans might use potatoes.

\section{HISTORY}

Chestnut is probably the most important nut crop in the temperate zone, ranking behind only coconut and peanut in importance. With species indigenous to all three continents of the Northern Hemisphere, the chestnut has long been cultivated throughout China, Korea, Japan, and the Mediterranean basin. In Asia, the Japanese chestnut (Castanea crenata) has been cultivated since the 1lth century, and the Chinese chestnut ( $C$. mollissima), possibly since 6,000 years ago. In the Mediterranean region, chestnuts have been cultivated for at least 3,000 years. The ancient Greeks are thought to have been among the first Europeans to cultivate the nut, introducing the European chestnut (C. sativa) from Asia Minor, via Turkey, to southern Europe and North Africa.

Table 3. Food value of chestnuts

\begin{tabular}{lccccc}
\hline Form & Water (\%) & Protein (\%) & Fat (\%) & Carbohydrates (\%) & Calories/oz \\
\hline Fresh & 44 & 4 & 1 & 49 & 64 \\
Dried & 9 & 7 & 2 & 80 & 103 \\
Boiled & 62 & 3 & 1 & 34 & 44 \\
Roasted & 40 & 4 & 1 & 52 & 68 \\
\hline
\end{tabular}

SOURCE: USDA Agriculture Handbook 1994. 
The importance of chestnuts in past civilizations cannot be overemphasized. The nuts served as year-round food for people and animals. In the colonization of America, the American chestnut (C. dentata) was the premier tree, providing wood for railroad ties, house framing, barns, fences, and fuel; tannin for leather processing; and, of course, the highly palatable nuts for human and wildlife consumption.

In the early 1900s, chestnut blight was introduced into this country, apparently from Asia. The blight-susceptible American chestnut was all but eliminated by 1950 . With it went dependence on a single tree species for so many important uses. Many of the present generation of Americans have never seen a chestnut tree and do not know what chestnuts taste like. While no wood has replaced the versatility and durability of the American chestnut, the larger, imported European chestnut (C. sati$v a)$ has replaced the native chestnut in the marketplace. Some people think it is an inferior substitute for the sweeter American chestnut of years past.

\section{WORLD CHESTNUT PRODUCTION}

Current chestnut production worldwide is about 500,000 tons $(454,000$ metric tons) which is distributed as follows: China, 40 percent; Korea, 15 percent; Italy, Turkey, and Japan, about 10 percent each; France, Spain, and Greece, about 4 percent each; and the United States, Australia, New Zealand, Chile, and Argentina, less than 1 percent each.

\section{Asia}

China is currently the world's largest producer and exporter of chestnuts with an estimated production of 110,000 to 265,000 tons ( 100,000 to 240,000 metric tons) annually. About one-third of the annual harvest is exported to Japan. From southern to northern China, 300 different cultivars are grown under diverse and variable climatic conditions and environments, but only about 50 cultivars are produced commercially. China is the low-cost producer that sets the market price in Asia. Chinese cuisine uses chestnuts in many dishes. Most of the nuts are consumed fresh or roasted in October, November, and December when they are first available. The popular Dragon-Boat Festival around May uses up most of the dried chestnuts.

The world's second largest producer of chestnuts is Korea, with up to 80,000 tons (73,000 metric tons) per year, of which up to 30,000 tons (27,000 metric tons) are exported to Japan; some are also exported to the United States. Yields of 0.7 to 3.6 tons per acre (1.6 to 8.1 metric tons/ha) are reported from plantings of about 160 trees per acre (395/ha), with one-third pollenizers. Most production is by Castanea crenata (Japanese cultivars) grown on seedling rootstock.

Japan is a large chestnut producer and consumer and is the biggest chestnut importer. Japan has a long history of chestnut cultivation. The domestic production is chilled fresh and consumed throughout the winter, especially around the New Year. Another method is to boil the nuts, cut them in half, and eat the nut meat with a teaspoon. Japanese chestnut prices range from $\$ 3.00$ to $\$ 4.00$ per pound for ordinary cultivars. The very best varieties can sell for $\$ 7.00$ to $\$ 8.00$ per pound.

\section{Europe}

Most European chestnuts are produced from managed native forest. Italy is the largest chestnut producer in the European Community at over 50,000 tons (45,400 metric tons) per year. Italy is also the world leader in the production of marrone glace and other processed chestnut products. To produce marrone glacé, the nut is stored for a period (chilled), which allows the shell and pellicle to be removed more easily from the nut by steam blasting. The nut is then frozen, thawed, and preserved with 
sugar liquor to a candied consistency. A box of marrone glacé chestnuts is more expensive than a box of fine chocolates.

In Italy, the traditional use of dried chestnuts and chestnut flour in cooking is declining, but overseas, the popularity of these and similar products is increasing, especially in the United States. Prices for processed, peeled, and frozen chestnut products in the United States have reached more than $\$ 2.75$ per pound, prompting moves to expand the chestnut industry.

The chestnut industry in France, which produces about 25,000 tons (23,000 metric tons) per year, has declined considerably from what it once was, due mostly to conversion to other more valuable crops and urbanization. In the European Community, France is now the biggest chestnut importer, mostly from Italy, but also from Spain and Portugal.

Spain produces about 20,000 tons (18,100 metric tons) per year, serving a large local market and exporting some to Italy and France. Chestnut lumber production is also a major consideration, with some cultivars specifically selected for timber rather than nut production. Phytophthora root rot is a major limitation of chestnut production throughout much of Europe.

\section{Southern Hemisphere}

Australia, New Zealand, Argentina, and Chile have recently begun to produce chestnuts primarily for export. Australia has even established a growers' association. Production is for both nuts and timber. Harvest begins in March and is complete by April. Stored nuts are shipped from March through May.

\section{United States}

In the United States, the first settlers found extensive native forests of the American chestnut (Castanea dentata) from Maine to Georgia. European chestnuts were introduced in the early 1700s, Japanese chestnuts by 1860 , and Chinese chestnuts in the late 1800s. In the early 1900s, however, the accidental introduction of chestnut blight destroyed almost all $C$. dentata and most introduced $C$. crenata and $C$. sativa plantings by the 1950s. Because chestnut blight killed almost all the native trees, extensive efforts are under way to reestablish the natural chestnut forests of the country. This has been the main concern of most chestnut researchers and supporters east of the Rocky Mountains, where most growers have planted the blight-tolerant Chinese chestnut (C. mollissima) or its hybrids. Planting stock is predominantly open-pollinated seedlings. Michigan growers have also planted several Korean varieties of chestnuts and 'Colossal' for trial.

There are an estimated 300 acres (120 ha) of chestnut trees in Oregon and Washington. Most of these plantings are less than 10 years old. The plantings are primarily 'Colossal,' but some growers are trying Dunstan hybrids and varieties like 'Skookum,' 'Lyeroka,' and 'Myoka.' Growers have formed a chestnut growers' association to foster information exchange and marketing.

Chestnuts were brought to California by immigrants during the Gold Rush mostly as seed of the European chestnut, but some chestnuts of mixed origin and grafted varieties were also introduced. Small old plantings still exist in the Sierra Foothills as well as in the North Coast and Central Valley. Within the last 15 years, there has been an increase in the plantings of chestnuts to an estimated 600 acres (240 ha), with about half of that acreage bearing. Most of the planted trees are either 'Colossal' or its seedlings, and most of the plantings are under 5 acres ( 2 ha) in size, with a few from 6 to 20 acres ( 2.5 to $8 \mathrm{ha}$ ) and a few from 21 to 80 acres (8.5 to 32 ha). 
The original 'Colossal' tree is still standing in Nevada City. It was planted by Benjamin Tonella, a Swiss-Italian immigrant who also planted apples, pears, and walnuts on the property, which he purchased from Felix Gillet, owner of Barren Hill Nursery. C. E. Parsons bought the nursery in 1908 after Gillet died, renamed it the Felix Gillet Nursery, and introduced seedling and grafted chestnuts from the original 'Colossal' tree. The tree today is 70 feet $(21 \mathrm{~m})$ tall with a trunk circumference of 14 feet $(4.3 \mathrm{~m})$ and an annual production of 300 pounds $(136 \mathrm{~kg}$ ) of nuts. Numerous small 'Colossal' seedling-tree orchards have also been planted that have produced several named selections.

\section{CONSUMPTION}

Although worldwide demand (see table 4) for chestnuts exceeds the demand for walnuts or almonds, the absence of a U.S. domestic industry after the disastrous loss of the native chestnut has seen chestnuts fade from common use in North America. Most contemporary Americans have never tasted a chestnut, but everybody has heard of them, and eagerness to sample that first chestnut is almost universal. Those who taste them, including children, like them, and some consumer tests indicate ready and enthusiastic acceptance by the American consumer. The United States has the greatest potential for expanding new chestnut plantings of any area in the world.

The United States annually imports 10 to 20 million pounds (4.5 to 9 million $\mathrm{kg}$ ) of European in-shell chestnuts, primarily from Italy, at a retail cost of $\$ 30$ to $\$ 40$ million. The annual value of imported processed chestnuts is estimated to be $\$ 500,000$. Import prices range from $\$ 1.50$ to $\$ 3.00$ per pound, with an average of $\$ 2.10$ per pound. The United States would need to produce chestnuts on 5,000 acres (2,000 ha) just to displace imports. Should the domestic consumption level rise to only 1 pound $(0.45 \mathrm{~kg})$ per capita, the United States would require over 100,000 acres $(40,500 \mathrm{ha})$ of mature production to meet that demand. Such an industry could be worth $\$ 600$ to $\$ 800$ million annually.

\section{ECONOMICS}

In the 1990s, very large California chestnuts commonly sold for $\$ 3.00$ per pound wholesale; organically produced nuts sold for an even higher price. The wholesale price ranged from $\$ 1.20$ to $\$ 5.00$ per pound, depending on the grade, market season, and location. Retailers commonly doubled the wholesale price and paid the best prices for the largest sizes. The size of the individual chestnuts is important in the more choosy fresh markets. Large nuts, 0.5 to 1 ounce (14 to $28 \mathrm{~g}$ ) each, may well command a premium price as high as $\$ 6.00$ to $\$ 7.00$ per pound at retail markets.

Production costs vary greatly depending on the growing site and the management practices used. On a good site, a mature orchard should yield 1.5 tons per acre

Table 4. World per capita consumption of chestnuts

\begin{tabular}{lll}
\hline County or region & Approximate annual per capita consumption \\
\hline Korea & $\mathbf{l b}$ & $\mathbf{k g}$ \\
Japan & 4.0 & 1.8 \\
Europe & 1.2 & 0.5 \\
China & 1.0 & 0.45 \\
United States & 0.5 & 0.2 \\
\hline
\end{tabular}

SOURCE: Proceedings of the Second Pacific Northwest Chestnut Congress August 22-23, 1987, Oregon State University. 
(3.4 metric tons/ha). It is expected that as knowledge and experience accrue on chestnut production in North America in the coming years, and with the development of improved cultivars and cultural practices, per-acre yields will rise.

Assuming a wholesale price of $\$ 2.00$ per pound for large-sized chestnuts, the gross return to growers would be $\$ 6,000$ per acre per year. The yield at full commercial maturity, 30 to 80 pounds ( 13.6 to $36 \mathrm{~kg}$ ) of nuts per tree, would project positive cash flow 10 to 15 years after planting if land costs are not too high. The length of productive commercial life of trees can be over 100 years.

Anyone considering an investment in a chestnut orchard should evaluate production costs, earning potential, and tax consequences, and make comparisons with alternative investments.

\section{MARKETING}

California chestnut harvest and sale begins from mid-September to the first week of October in most years, later in cooler locations. Most of these nuts are sold by Thanksgiving. Thanksgiving through the New Year is the time of the highest demand, which is filled by nuts imported mostly from Italy and Korea. Italian chestnuts are sold for about $\$ 2.00$ per pound wholesale and have been consistently available throughout the holiday season.

Some buyers prefer Italian chestnuts because of their consistent quality (large sizes and easy peeling) compared to to the inconsistent quality of California chestnuts (mixed sizes, various colors, and difficult peeling). Recently, with the introduction of uniformly large and high-quality nuts from California, that image is changing.

Sales are mainly to specialty ethnic markets, health food stores, farmers' markets, and from roadside stands. Ethnic markets make up the greatest outlet for chestnuts, perhaps as high as 80 percent in some locations. Most of the remaining nuts are sold to upscale consumers for special recipes during the holidays. Chestnuts are an expensive food item and complicated to prepare for people not familiar with them. Most are sold fresh in the shell, but some Italian delicatessens also sell dried, peeled chestnuts. There is likely a potential to increase consumption through marketing and promotion programs, especially since chestnuts are considered a health food that is delectable and can easily be grown organically. These positive aspects appeal to many of today's consumers.

Since freshness is a sales factor in chestnut appearance, domestic production has a definite advantage over Europe and Asia due to early ripening. When preholiday sales become saturated, the nuts are stored for sales between Thanksgiving and Christmas in direct competition with imported nuts. Storage conditions are very important in preventing the nuts from molding (see "Storage," below). There have been problems reported with chestnuts molding and drying on the shelf, especially nuts that have experienced poor storage conditions during transport by sea from Europe or Asia.

\section{CULTURAL PRACTICES}

In Europe and Asia, people have harvested nuts from chestnut groves and forests for thousands of years. Chestnut production there is virtually a harvest-only system, with livestock grazing the chestnut stands for all but the annual harvest period. In many climates chestnuts are survivors and will continue to produce fruit with no soil cultivation, no pesticide sprays, and no fertilizer inputs. 
Given the original range of the American chestnut and the broad range in Europe and Asia, it is fair to say that the range of commercial plantings in North America could be geographically diverse. Variety selections and cultural practices will likely vary throughout this huge area. Land ideally suited to chestnut production is plentiful throughout much of the United States. In California, however, the production of economically competitive yields and large nuts will require management that is much more intensive. Getting the trees off to a vigorous start is the first step.

\section{Site preparation}

Chestnut trees thrive on a variety of site and soil conditions and have traditionally been grown on hilly land that is unsuitable for row crops. Light, well-drained soils are optimal since chestnut trees are intolerant of wet soil conditions. Standing water during any part of the season depletes soil oxygen, and saturated soil is very conducive to Phytophthora root rot infection, which is the most common disease in chestnuts. Chestnuts will tolerate low-pH (acidic) soils very well but do not tolerate high-pH (alkaline) soils.

Soil tests for potassium, phosphorous, calcium, magnesium, and $\mathrm{pH}$ should be conducted prior to planting trees. Alkaline soils can be acidified by the addition of sulfur or aluminum sulfate to a desirable $\mathrm{pH}$ of slightly below neutral (below 7.0). Soils that are extremely acidic (below 5.5) should be amended with the addition of lime to a $\mathrm{pH}$ of approximately 6.5 . Soil and irrigation water tests for micronutrients may need to be conducted if excess nutrients may be a problem. Choices of liming materials, the need for gypsum and subsequent leaching of sodium salts, or special circumstances with high-magnesium or low-calcium soils should be corrected before planting the trees. Contact your local Cooperative Extension farm advisor for specific recommendations.

The orchard site should be properly prepared before planting. Ripping and breaking up subsoils by mechanical means has proven very helpful to the development of strong root systems if there is an existing subsoil or compaction problem. Leveling or proper installation of drainage is very important. Mounding and planting trees on top of a soil berm or windrow allows for better drainage at the tree crown and also helps prevent root and crown rot. Soil fumigation or solarization is recommended if oak root fungus is present.

The ground should be free of any perennial weeds, because once the trees are established weed control is more complicated and costly. A cover crop planted the previous year, cultivation, or herbicide application can help remove noxious or problem weeds.

\section{Planting and training young trees}

Care should be taken to spread the young roots in the planting hole and to plant the tree at the proper depth. Plant the trees at the same depth they were in the nursery or slightly higher. Do not plant the trees too deep. Watering the tree after planting will ensure good soil-to-root contact. Subsequent weekly irrigations once growth begins are necessary to keep the soil moist and the young tree actively growing.

Chestnut trees need to be trained during their formative years to develop a desirable structure, the modified central leader system used for walnuts (See Walnut Production Manual, DANR Publication 3373, 1998). Cut back the top of the tree to approximately 36 to 48 inches ( 90 to $120 \mathrm{~cm}$ ) tall to compensate for roots lost during digging in the nursery. A single new leader is typically trained up a stake the first 


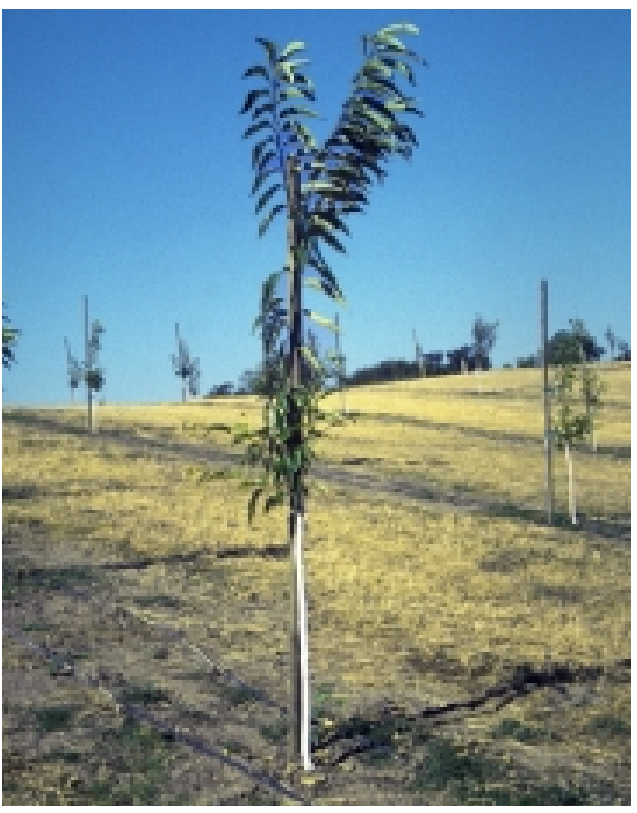

Figure 8. A chestnut tree in its first growing season that has been trained to a single leader. Note that there is no branching below 42 inches $(1 \mathrm{~m})$ from the ground.

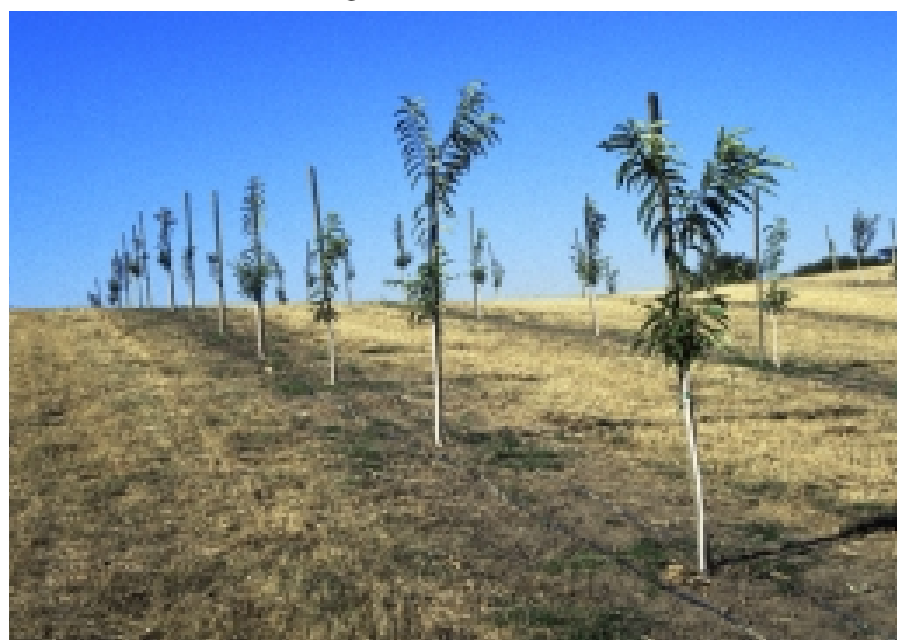

Figure 9. New orchard of closely spaced trees.

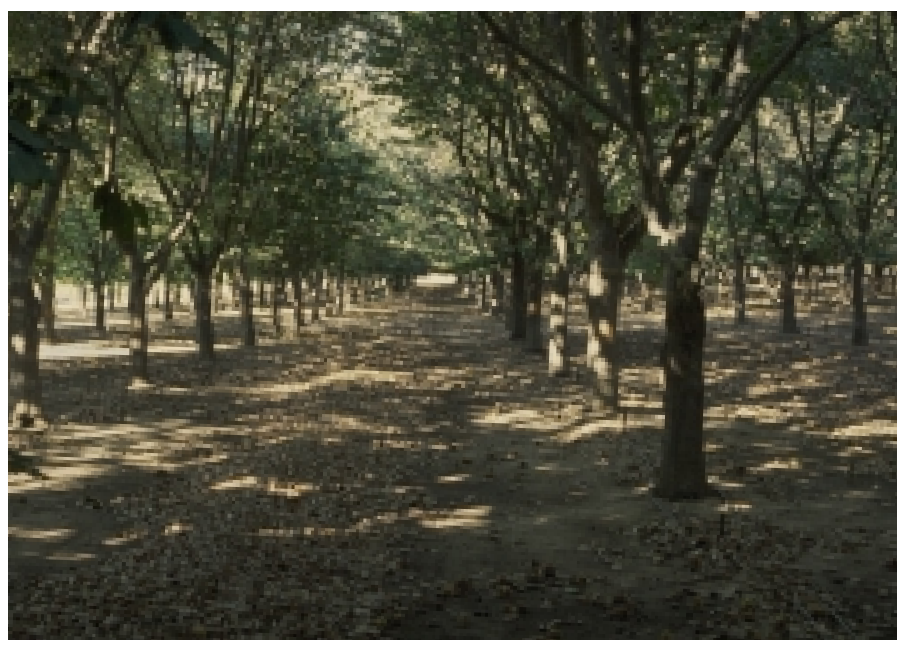

Figure 11. Twelve-year-old orchard with crowded trees and excessive shading of lower branches. growing season (see fig. 8). If the grower anticipates mechanical harvest with shakers, the first scaffold branch should be at least 42 inches (1 m) from the ground. Branches originating lower than that can be removed during dormant pruning at the end of the first growing season. The scaffold branches are selected during the second through the sixth growing seasons, allowing for good spacing between branches on the main trunk.

\section{Tree spacing}

Trees can be planted from 14 to 40 feet (about 4 to $12 \mathrm{~m}$ ) apart, depending on the grower's willingness to remove every other tree when crowding occurs (see fig. 9). The closer spacings will eventually require thinning of trees in order to maintain high yields and uniform bearing throughout each tree (see fig. 10). Crowded trees tend to create excessive shading on lower branches and promote bearing only on one plane in the tops of the trees, limiting production. Severely shaded lower branches will die (see figs. 11 and 12).

Without topping or shaping, chestnut trees eventually grow to a height of 35 to 40 feet (10 to $12 \mathrm{~m}$ ); timber-form trees can reach 100 feet $(30 \mathrm{~m})$. Large timber-form trees are not desirable for nut production because they are more difficult to manage and much of the tree's energy

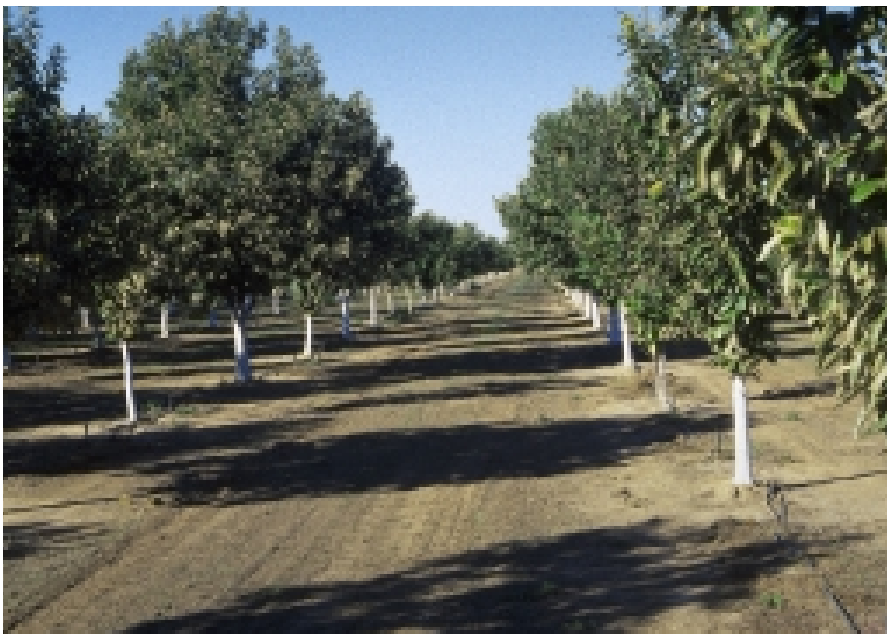

Figure 10. Eight-year-old orchard. The trees are just beginning to touch each other.

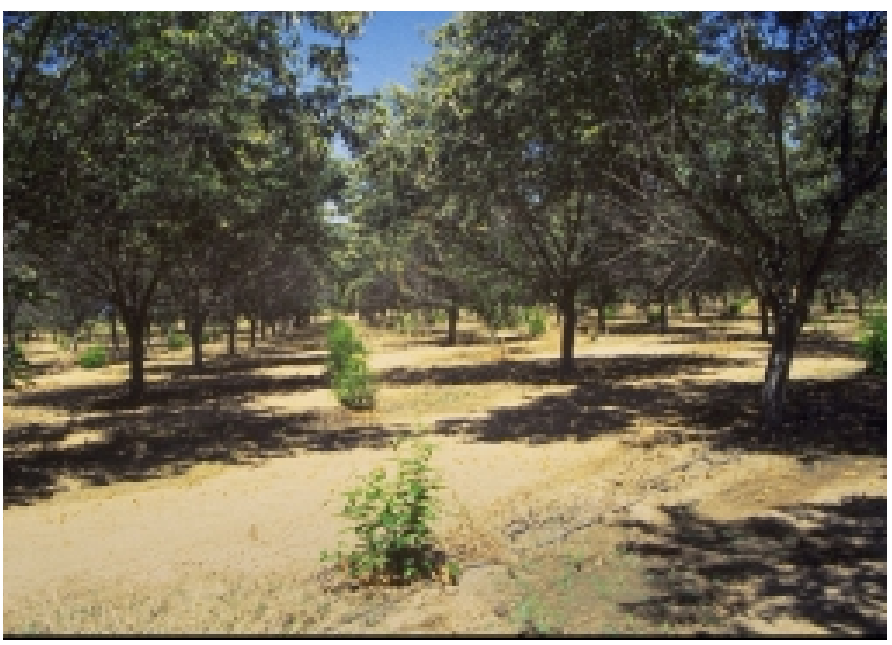

Figure 12. Fifteen-year-old orchard with every other row removed. 
goes into wood production rather than nut production. A management strategy calling for little pruning or tree thinning should plan on a minimum spacing of 30 to 40 feet $(9$ to $12 \mathrm{~m}$ ) on all sides, resulting in about 27 to 48 trees per acre (67 to 120 per ha). Denser chestnut plantings with tree spacings from 14 to 25 feet ( 4 to $7.5 \mathrm{~m}$ ) have been popular, resulting in about 70 to 200 trees per acre (175 to 500 per ha), because they provide greater return per acre in the early years; but they require tree thinning as the canopies begin to touch. The hedgerow system of trees, closer within the row than between rows, is more efficient for floor management and irrigation layout (see The Walnut Hedgerow Planting System, DANR Publication 21467, 1999).

Pollenizer trees should be planted at a ratio of 1 pollenizer cultivar for every 8 to 10 trees of the main cultivar. If the nut of the pollenizer cultivar is different in size, color, or maturity date than the main cultivar, the pollenizers should be planted in separate rows to facilitate harvest and separation. Small orchards should have the pollenizer trees planted upwind from the main cultivar.

\section{Weed control and orchard floor management}

No other single cultural practice is as important as controlling competing vegetation during the establishment phase (the first 3 to 4 years) of a chestnut planting. A competition-free zone extending about 3 to 6 feet $(1$ to $2 \mathrm{~m}$ ) in all directions from the trunk on young producing trees has proven very beneficial. Once a tree has reached 6 to 8 years of age and is producing regularly, weed control is somewhat less essential; many weeds become shaded out underneath the trees.

Although chestnut trees start out with a taproot, soil conditions dictate the extent of the root system. The majority of the essential fine feeder roots are within about 2 to 3 feet ( 0.6 to $1.0 \mathrm{~m}$ ) of the surface. Cultivation, mulching, herbicides, and mowing are used in various combinations to make sure young trees get the advantages they need to stay strong. As trees mature and reach bearing age, a clean, hardpacked surface from the trunk to the drip line of the tree is essential for nut harvest. Weed or cover crop vegetation can be mowed closely with a flail mower prior to harvest to obtain a clean surface.

Both preemergent and postemergent herbicides are available for use in chestnut orchards. Consult your local Cooperative Extension office for information on the safe and effective use of herbicides. Synthetic fabric mulches are also very effective for weed control as an alternative to herbicides. Other alternatives include various cultivation devices such as hydraulic rotating weeders, reciprocating roto-tillers, and cutting-blade devices.

\section{Fertilization}

Nitrogen is usually the element most needed by chestnut trees; studies have shown that nitrogen supplements have positive benefits for production and nut quality. The amount of nitrogen required depends on the soil conditions and the size and age of the tree. Limited growth in the terminals and yellowing leaves indicate nitrogen deficiency. Fertilizer programs should be used in conjunction with periodic soil tests. No standards for leaf analysis have been established.

Care should be taken not to apply fertilizers in the planting hole since this can cause root burn. Fertilization programs should begin when growth begins in the spring. The application of about 100 pounds of actual nitrogen per acre $(112 \mathrm{~kg}$ nitrogen per ha) per year is adequate for a mature chestnut orchard. Young trees should receive a fraction of the mature rate based on estimated fill-in of the orchard. For example, trees shading 40 percent of the orchard floor should receive 40 pounds of actual nitrogen per acre per year. For newly planted trees in a spacing of 30 feet by 30 feet ( 48 trees per acre), apply 9 ounces per tree in the first year plus 2 to 3 
ounces of actual nitrogen to each tree per year; in a spacing of about $9 \mathrm{~m}$ by $9 \mathrm{~m}$ (about 118 trees per ha), apply 57 to $85 \mathrm{~g}$ of actual nitrogen. Increase this rate of application by 2 to 3 ounces ( 57 to $85 \mathrm{~g}$ ) of actual nitrogen to each tree every year until 100 pounds of actual nitrogen are applied per acre (112 per ha). Closer tree spacings with more trees per acre require lower amounts per tree. Apply the fertilizer from the drip line to within 2 feet $(60 \mathrm{~cm})$ of the trunk before irrigation. For dripirrigated orchards, small amounts of fertilizer can be placed under emitters periodically; do not exceed 1 ounce ( $28 \mathrm{~g}$ ) of conventional fertilizer material per application per emitter.

Since most soils in California have an adequate supply of phosphorous, it is not usually needed as an added nutrient. Potassium, however, is often missing and should be applied when needed in large quantities, such as 500 pounds of potassium sulfate per acre $(560 \mathrm{~kg} / \mathrm{ha})$, in a band just inside the drip line of the tree. Large quantities are applied to a concentrated area because small quantities of potassium normally become tied up by the soil and are rendered unavailable to plant roots.

Materials such as compost, feather meal, blood meal, manure, and mined minerals classified as organic can also be used to fertilize chestnuts. They typically contain a low concentration of several nutrients that become available for plant uptake as they slowly break down. Their rates should reflect the application of approximately 100 pounds of actual nitrogen per acre $(112 \mathrm{~kg} / \mathrm{ha})$ in a mature orchard. Young tree rates are calculated as a percentage of the leaf cover of the orchard.

Leguminous cover crops can also be grown to provide nitrogen fixed in their root nodules and to make available other nutrients from the lower soil profile (see Cover Cropping in Vineyards, DANR Publication 3338, 1998). Cover crops should be seeded in the fall of the year right after harvest when soils are still warm in order to get good seed germination and early growth. For large-seeded legumes such as vetch or bell beans, cultivation is required in the fall to prepare a seedbed prior to plant-ing and in the spring to incorporate the organic material. Another method is to use selfseeding legumes such as subterranean clover or rose clover and mow the cover crop in the spring. These cover crops must be established in a well-prepared seedbed the first year, but they come back on their own with fall and winter rains. Cover-cropped orchards usually require more irrigation than orchards that are not cover-cropped.

\section{Irrigation}

Chestnut trees are remarkably drought resistant, but water stress can lead to smaller nut size and lower yields. Trees can easily become water stressed in the dry California summers, especially if grown on light-textured or shallow soils. Irrigation of chestnut trees should be based on the evapotranspiration rate for the time of the growing season. Sprinkler- or surface-irrigated orchards on sandy loam soils usually require a deep irrigation every 2 to 3 weeks to a depth of 3 to 4 feet (90 to 120 $\mathrm{cm}$ ) from May to September. Drip- or microsprinkler-irrigated orchards need a continuously moist soil in order to foster good tree growth and nut size. For drip irrigation, this means daily or every-other-day applications; microsprinklers are usually run twice per week.

\section{Diseases and pests}

Chestnuts are very susceptible to Phytophthora crown and root rot (Phytophthora spp.), which is the most prevalent disease of chestnuts in California. Infected trees usually collapse as hot weather begins in the spring (leaves turn yellow-brown, followed by death of the branches and trunk). Brown to black streaking can be observed in the water-conducting vessels of the wood, just under the bark. This fungal disease can be prevented by selecting planting sites with good internal soil 
drainage and using irrigation management strategies that avoid prolonged periods of saturated soil. Modifying the drainage by providing good surface drainage and/or underground tile systems and planting on raised mounds can also help. The soil immediately surrounding the tree trunks should be kept as dry as possible at all times of the year.

The most notorious chestnut disease is the chestnut blight (Endothia parasitica, renamed Cryphonectria parasitica). This fungal bark disease is very threatening to the European (Castanea sativa) and American ( $C$. dentata) chestnut trees. Fortunately, our best orchard selections are hybrids involving C. mollissima, the most blight-resistant of the Castanea genus, having coevolved in Asia with the blight organisms for thousands of years. Chestnut blight is present in California but is not spreading under our conditions. 'Colossal' trees infected with chestnut blight in California are not dying even after years of infection. This indicates that the trees are not immune but can tolerate the disease without much ill effect. For propagation, West Coast nurseries and growers are using American, Asian, and European hybrids. These nurseries rely on varietal tolerance, isolation, and quarantines of plant material to prevent introduction and spread of the blight into their orchards.

Oak root fungus (Armillaria mellea) has been known to kill chestnut trees. Preventing this disease through soil fumigation and planting in areas free of the disease are the current means of control. Ultimately, the use of resistant rootstocks is the best biological control tactic, but research must be conducted to evaluate the level of resistance in potential rootstocks.

The worst insect problems associated with chestnuts are caused by the shot hole borer (Scolytus rugulosus), chestnut weevils (Balanius rectus and Curculio elephas), clearwing chestnut moth (Synanthedon castaneae), Oriental chestnut gall wasp (Dryocosmus kuriphilus), and filbert worm (Cydia latiferreana), none of which is currently a significant problem in California. Shot hole borer and chestnut weevils have been identified as minor pests. Maintaining adequate vigor in the trees through irrigation management and reducing stress factors on the trees prevents shot hole borer infestation, which has been a problem in other growing areas. Chestnut weevils are controlled through sanitation and storage conditions that prevent their introduction. There are very few pesticides registered for use on chestnuts in California. At present, spray programs are not required in chestnut groves, so there is a good opportunity to grow the trees organically.

Young chestnut trees are very vulnerable to attack by deer and gophers. The orchard must be fenced to exclude deer if they are present. Gopher baits and traps are the only sure way to eliminate damage from underground feeding. Wild pigs also eat fallen chestnuts and should be controlled, fenced out, or the nuts must be harvested daily to minimize losses.

\section{Pruning}

Chestnut production comes from flowers borne on the current season's growth, which originates from last year's shoot growth, much like the walnut varieties 'Hartley' and 'Franquette.' Heading-type pruning cuts can be used to develop more branching in the early years, but as the trees come into bearing, heading cuts will reduce yield. Mature trees should be pruned to remove dead or weak branches, water sprouts, and branches that hinder cultural operations. Some branch thinning may be necessary to allow sunlight exposure into the tree and to maintain fruiting wood. Heavy pruning invigorates vegetative growth but diminishes and delays production. Alternate-year pruning as conducted with some other tree species with similar bearing habit may be feasible. 


\section{HAR VEST}

Chestnuts are hand-harvested in Europe and Asia with methods little changed over the past 2,000 years. The scarcity of farm labor and the changing cost structure in

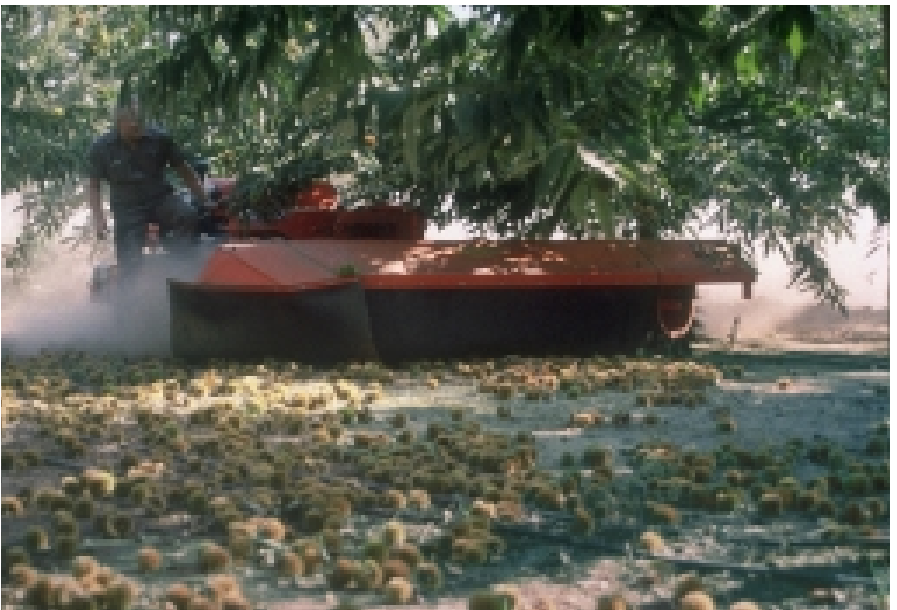

Figure 13. A chestnut sweeper moving nuts into a windrow.

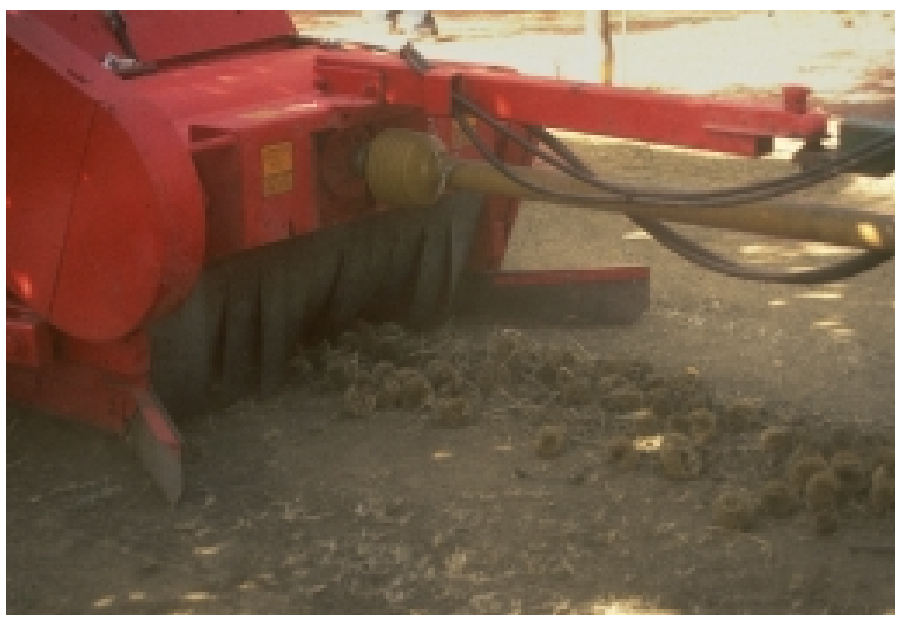

Figure 14. A pick-up machine for chestnuts.

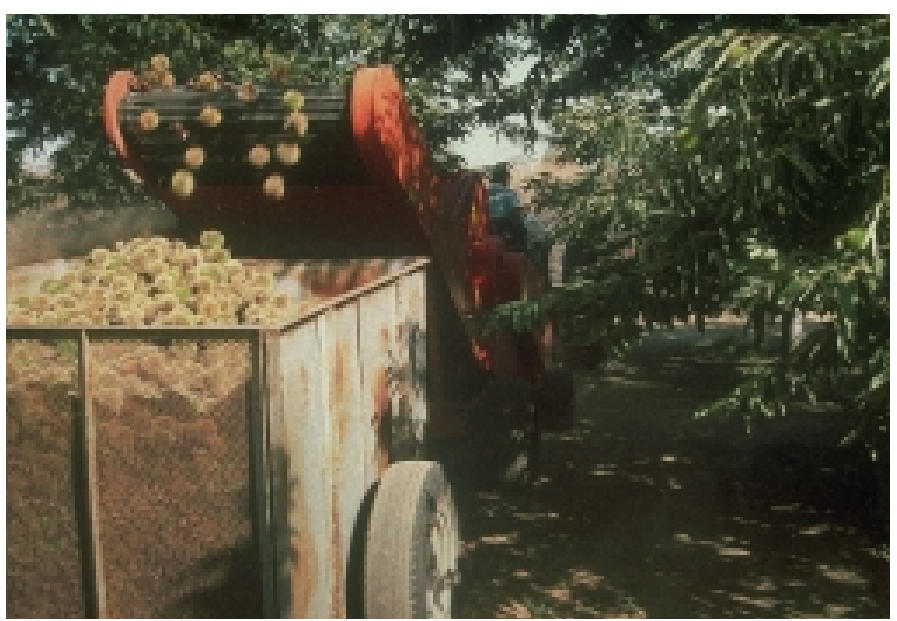

Figure 15. A conveyor belt from a pick-up machine loads chestnuts into a bin. agriculture dictate, however, the need for mechanically assisted harvesting options. The simplest harvesting method is to let the nuts fall to the ground naturally, step on the burrs to separate the nuts, and then pick them up by hand. New, low-cost polypropylene net tarps can help reduce collection costs for small-scale operations. A multiacre orchard would have a natural nut drop period of 10 to 15 days in most years, but it may range up to 30 days in some years, depending on environmental conditions. During these extended harvest periods, the nuts are subject to fungal infection and drying out. Fallen nuts should be picked up at least every 2 days.

The splitting and opening of the burrs is a sign that the nuts inside are mature (usually from mid-September to mid-October). Chestnuts add much of their final weight during the last 2 weeks on the tree. If mechanical shakers are to be used, it should be done as late as possible in order to maximize yield and nut quality. Mechanical shaking may need to be done more than once and should not be done before natural nut fall begins. Although no mechanical system of chestnut harvest has been perfected to lower labor costs, some existing harvesting techniques for other crops, such as walnuts or filberts, may be adaptable to chestnuts (see figs. 13, 14, and 15). It is easy enough to pick up the nuts and burrs with conventional almond, walnut, filbert, or pecan sweepers, but the main problem is separating the nuts from the burr.

Roller drums have been used that are similar to walnut hullers but separation is not complete and many of the nuts are scratched. One California grower has developed a wringer-type separator made from tires (see fig. 16) that squeezes and twists the burrs to pop out the nuts without scratching the shell. In Italy, some growers use a large vacuum device that is pulled through steep terrain to gather the nuts. The nuts are sucked into a rotating drum that separates the burrs from the nuts and sorts the nuts by size (see fig. 17).

On small orchards and for young trees, hand-harvest is the most viable option. It is estimated that one person could harvest a 10-acre (4-ha) planting consisting of 1,000 trees by hand. Hand-harvest also assures the highest quality since nutshells are not scratched. 


\section{STORAGE}

It is anticipated that most growers will sell their production as soon as the harvest is gathered fresh from the grove, thus eliminating any storage concerns. For shortterm storage, chestnuts should be treated more like apples than other nut crops such

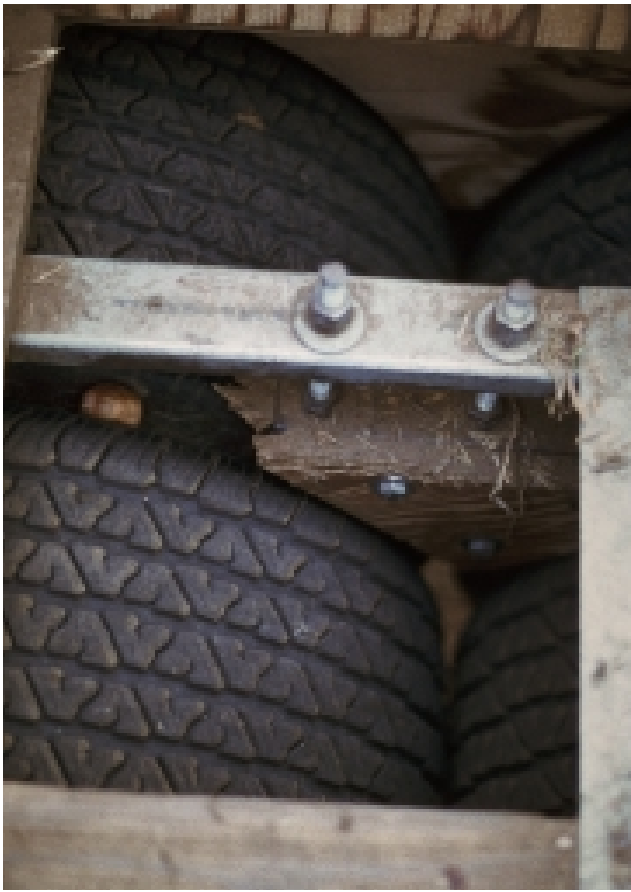

Figure 16. A chestnut wringer, made from tires, can be used to remove nuts from the burrs.

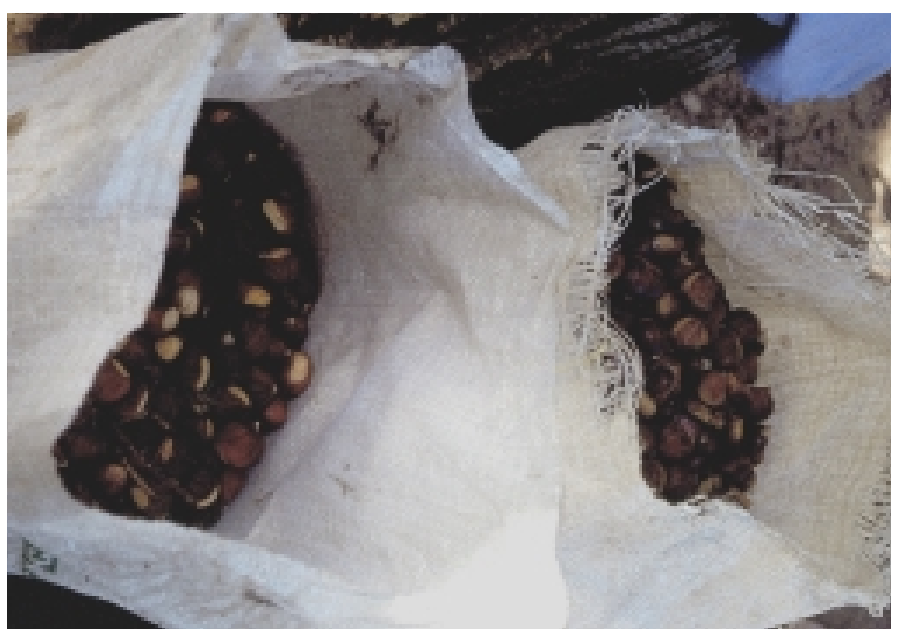

Figure 17. Sized chestnuts stored in sacks for transport to market. as walnut, filbert, or almond. Chestnuts should be washed thoroughly and cooled as soon as possible to $32^{\circ}$ to $33^{\circ} \mathrm{F}\left(0^{\circ}\right.$ to $\left.0.5^{\circ} \mathrm{C}\right)$ for storage. The relative humidity should be kept as high as possible. Chestnuts dry out, even at high humidity, so protective packaging is needed. Mold-inhibiting fungicides and controlledatmosphere storage would most likely improve chestnut quality in long-term storage.

For long-term storage, growers in some locations place fresh nuts in a cool water bath for 7 to 9 days and then into cold storage at $28^{\circ}$ to $33^{\circ} \mathrm{F}\left(-2^{\circ}\right.$ to $\left.0.5^{\circ} \mathrm{C}\right)$ and 70 to 80 percent relative humidity. Chestnuts held under these conditions will remain in excellent condition for up to 3 months, after which they begin to germinate (embryos with emerging radicals are still edible).

\section{PROPAGATION}

Chestnut seedling trees are quite variable in size, shape, and vigor. They are definitely not acceptable for commercial production. Each seedling tree is different, and seedling orchards produce mostly small nuts with a few large nuts in several sizes, shapes, and colors. Many of these nuts will also be very difficult to peel due to differences in pellicle thickness and adherence to the shell or cotyledons. There will also likely be flavor differences. For the production of a commercial crop of uniform size and quality, grafted trees are necessary.

Commercially, chestnut trees are produced by grafting a scion of the desired cultivar onto 1-year-old seedlings grown from nuts of the same cultivar. Graft incompatibility can develop when seedling rootstocks and scions are from different cultivars.

Nuts to be planted for seedling rootstocks should be stored in moist (not wet) peat moss in plastic bags. Generously puncture the bags using a toothpick or other device. Make sure each nut is surrounded by peat moss and does not touch other nuts or the side of the bag. Store at $34^{\circ} \mathrm{F}\left(1^{\circ} \mathrm{C}\right)$ until planting time.

Grafting a scion cultivar onto random seedlings from other cultivars may result in delayed incompatibility and eventually kill the tree in 1 to 10 years. Incompatibility is usually indicated by weakened, collapsing trees with a dark necrotic area at the graft union. Incompatible trees sometimes break cleanly at the graft union. The normal grafting methods used on other woody species (T-bud, chip-bud, whip grafting, etc.) are also generally successful with chestnut. Selfrooting the trees through layering, cuttings, or tissue culture is possible but very difficult. 


\section{B I B LI O G R A P HY}

\section{Books}

Bergantz, R. 1987. Experiences with the California chestnut industry. In Proceedings of the Second Pacific Northwest Chestnut Congress, Oregon State University. $33-51$.

Bhagwandin, Omroa. 1994. An update on growing and marketing chestnuts on the Pacific Coast. In Proceedings of the 85th Annual Report of the Northern Nut Growers Assn. 133-139.

Graves, A. H. 1949. Key to chestnut species, with notes on some hybrids. In Proceedings of the 40th Annual Report of the Northern Nut Growers Assn. 95-107.

Huang, H., J. D. Norton, G. E. Boyhan, and B. R. Abrahams. 1994. Graft compatibility among chestnut (Castanea) species. In Proceedings of the 85th Annual Report of the Northern Nut Growers Assn. 140-148.

Ingels, C. A., R. L. Bugg, G. T. McGourty, and L. P. Christensen, eds. 1998. Cover cropping in vineyards: A grower's handbook. Oakland: University of California Division of Agriculture and Natural Resources, Publication 3338.

Jaynes, R. A. 1979. Chestnuts nut tree culture in North America. In Proceedings of the 70th Annual Report of the Northern Nut Growers Assn. 111-127.

Lagerstedt, H. 1987. A review of chestnut propagation. In Proceedings of the Second Pacific Northwest Chestnut Congress, Oregon State University. 56-61.

Rackham, R. L. 1992. Growing chestnuts in Oregon. Oregon State University, Linn and Benton Counties, Extension publication.

Ramos, D., ed. 1998. Walnut production manual. Oakland: University of California Division of Agriculture and Natural Resources, Publication 3373.

Read, P. E., M. A. Hosier, and Y. Qiguang. 1985. Tissue culture of chestnuts. In Proceedings of the 76th Annual Report of the Northern Nut Growers Assn. $142-146$.

Rutter, P. 1987. Chestnut ecology and the developing orcharding industry. In Proceedings of the Second Pacific Northwest Chestnut Congress, Oregon State University.

Sibbett, G. S., L. C. Hendricks, and W. O. Reil. 1999. The walnut hedgerow planting system. Oakland: University of California Division of Agriculture and Natural Resources, Publication 21467.

Smith, A. H. 1976. The chestnut. In California Rare Fruit Growers Yearbook, vol. 8. 15-51.

Stebbins, R. 1987. The requirements for establishing a chestnut industry. In Proceedings of the Second Pacific Northwest Chestnut Congress, Oregon State University. 106-113.

USDA Agriculture Handbook. 1994. Nos. 8-12. Washington, D.C.: USDA.

Wallace, R. D. 1987. History of breeding and production of hybrid chestnut cultivars. In Proceedings of the Second Pacific Northwest Chestnut Congress, Oregon State University. 24-29. 


\section{Resources}

Conservation of Minor Fruit Tree Species website, www.unifi.it/project/ueresgen29/

The Western Chestnut (Western Chestnut Growers Association newsletter). P. O. Box 841, Ridgefield, WA 98642, rayoung1@ix.netcom.com

The Nutshell (Quarterly Newsletter of the Northern Nut Growers Association). 654 Beinhower Rd., Etters, PA 17319-9774, www.icserv.com/nngal

\section{FOR MORE INFORMATION}

You'll find detailed information on many aspects of weed management in these titles and in other publications, slide sets, and videos from UC ANR:

Diseases of Temperate Zone Tree Fruit and Nut Crops, publication 3345

Fertilizing Home Fruit Trees, Nut Trees, and Grapevines, publication 21329

Harvesting and Storing Your Home Orchard's Nut Crop, publication 8005

Training Young Fruit and Nut Trees, video 85-B

To order these products, visit our online catalog at http://anrcatalog.ucdavis.edu. You can also place orders by mail, phone, or fax, or request a printed catalog of publications, slide sets, and videos from

University of California

Division of Agriculture and Natural Resources

Communication Services

6701 San Pablo Avenue, 2nd Floor

Oakland, California 94608-1239

Telephone: 1-800-994-8849 or (510) 642-2431, FAX: (510) 643-5470

e-mail inquiries: danrcs@ucdavis.edu

An electronic version of this publication is available on the ANR Communication Services

website at http://anrcatalog.ucdavis.edu.

Publication 8010

(C) 2000 by the Regents of the University of California,

Division of Agriculture and Natural Resources. All rights reserved.

The University of California prohibits discrimination against or harassment of any person employed by or seeking employment with the University on the basis of race, color, national origin, religion, sex, physical or mental disability, medical condition (cancer-related or genetic characteristics), ancestry, marital status, age, sexual orientation, citizenship, or status as a covered veteran (special disabled veteran, Vietnam-era veteran or any other veteran who served on active duty during a war or in a campaign or expedition for which a campaign badge has been authorized).

University Policy is intended to be consistent with the provisions of applicable State and Federal laws. Inquiries regarding the University's nondiscrimination policies may be directed to the Affirmative Action/Staff Personnel Services Director, University of California, Agriculture and Natural Resources, 1111 Franklin, 6th Floor, Oakland, CA 94607-5200 (510) 987-0096.

pr-5/00-SB/WJC

ISBN 978-1-60107-190-3 